\title{
Toward Successful Career of Vocational Education Students through Improving Business Communication Skills
}

\author{
Suroto $^{1}$, Susilaningsih ${ }^{1}$, Harini $^{1}$ \\ ${ }^{1}$ Sebelas Maret University, Surakarta, Indonesia \\ Email: surotokarisma@gmail.com
}

\begin{abstract}
Global competition in the field of employment encourages educational institutions, i.e. schools, to improve the skills of their graduates. There are some skills required in the work place, known as transferable skills, which help students to win the competition in developing their career. One of these skills is presentation. The aim of this article is to build an understanding of the importance of business communication, especially business presentation, to the career success of vocational education students. This article is written by reviewing relevant literature. It is concluded that business communication skill including business presentation can facilitate vocational students in building their career in getting a job, continuing study, and starting a business as an entrepreneur.
\end{abstract}

\section{Keywords: Vocational Education, Career, Transferable Skills, Business Presentation.}

\section{INTRODUCTION}

Global competition currently is a problem encountered by every country in the world. It opens not only the flow of goods and services but also the professional labor market (educated and skilled in any field). Therefore, being highly educated without being accompanied by good skills and competencies is considered insufficient to encounter the competition. This phenomenon is shown by the increase in educated unemployment each year. Today, the number of educated unemployed (graduates from high schools, vocational high schools, or universities) in Indonesia is more dominant, reaching 3,792,560 (59.55\%) of total unemployment [1]. The phenomenon forces all stakeholders (governments, labor, and employers) to improve the quality of their Human Resources (HR), especially those related to skills and competencies. Vocational education, therefore, plays a significant role in improving skills and competencies.

Vocational education is education that implements a dual system (education in schools and on-the-job training). Such education is expected to be a solution for students who lack of skills and competencies. This expectancy is due to the significance of vocational school insisting that it is one of high schools [2] aimed to produce graduates with any desired skills [3] and to achieve a good career in a variety of hightech jobs, services, health, as well as traditional trades and crafts [4]. However, this education is considered to have less, rather than maximum, results. In fact, many graduates of vocational high schools are unemployed. This is known from the result of the Central Bureau of Statistics (BPS)'s survey in 2016 which shows that the number of 
unemployed vocational school graduates in Indonesia was $19.19 \%$ of the total number of unemployed or equal to 1.383 .022 (36.46\% of the number of educated unemployed).

The problem needs an immediate solution so that it does not get worse. Some competencies that can support the career of the graduates should be upgraded, one of which is business communication competencies related to business presentation. Business presentation is a form of verbal communication [5] which is inseparable from business careers [6]. Even Presentations are described as the bases of a sale [7]. Seeking work is essentially about promoting oneself, goods, or services so that others are interested in picking, hiring, or buying them. This article provides comprehensive discussion about the importance of business communication skill including business presentation in fostering vocational students' career.

\section{Potential and Career of Vocational Education Students}

Vocational schools provide some of the basic skills and special skills of students. The skills are expected to support them in finding jobs or starting their own business [8] and reducing the number of non-competent workers [9]. By learning in vocational schools, the students are expected to work in their special fields [10] and to compete for inter-state employment as well as to improve national employment qualifications [11].

Ahadi [12] claimed that vocational school students have several advantages, namely: (1) they are equipped with special skills so that when graduated they are ready to work, (2) they easily go to college in similar majors, and (3) they can easily open their own business by implementing the skills they have already possessed. Therefore vocational school students are expected to have good careers (jobs / positions).

\section{Problem of Vocational Graduates}

Vocational Schools are expected to be able to improve graduates' careers by preparing them to be ready to work, to start a business, or to continue their studies but in fact, it is less optimal. There are still many obstacles encountered by the vocational students after graduation. Some of them are the following: First, they are difficult to get a job due their lack of expertise poor performance in the job interview. Second, they are lack of expertise to start a business such as communication, negotiation and presentation skills. Third, they are lack of motivation to take a further study.

Since the vocational education prepares the students to work, it can reinforce them by providing skills demanded by the future labor market, namely: transferable skills. Transferable skills are basically vied from the users' perspective so that the skills are portable and are ready to be used in time to do the work in the workplace [13]. Some skills that can be categorized as transferable ones include teamwork, presentation and communication, and numerical framework. 


\section{BUSINESS COMMUNICATION AND BUSINESS PRESENTATION AS SOLUTIONS}

Communication is indispensable for achieving goals [14]. Business communication is a study of communication. It includes verbal communication and nonverbal one, which is used to achieve certain goals in the business world [15-17]. The business presentation is a form of verbal communication [18] or a form of integrated communication by means of voice, images, and body language. It is an integral part of a business career [19]. Even presentation is described as the body of a sale [20] and is one of the most important activities that support the achievement of a company's objectives [21]. Others argued that the presentation is related to the effectiveness of personal selling [22] for a good business presentation will have a good effect on the presenter [23].

\section{Communication Competencies and Business Presentation Related to the Successful Career of Vocational Students}

A person's career is influenced by his/her competencies [24-25]. The more competent a person is, the better his/her career will be [26]. Competence is one of the competitive advantages of an individual [27]. It is often represented as attributes of an individual including knowledge, skills, attitudes, traits, and motivation [28].

Business communication is one of the most important competencies to achieve good career [29-30]. A successful businesses communication is often related to writing and speaking well-meaning that it is articulated well, and it is one's fluency in arranging words [31]. Business presentation is a form of business communication. Viewed from the perspective of marketing communications, a business presentation includes face-to-face (personal) selling i.e. oral presentation in the form of a conversation, which is intended to sell something, before one or several potential buyers [32].

Vocational students are expected to be able to plan and achieve a good career by using the expertise they have. In fact, there are still many graduates who are unemployed and who have no business as well as no motivation for further study. This is not only due to the lack of knowledge that they get from schools but also other things such as the lack of ability to communicate that makes them uninformed, less able to socialize and to promote themselves well in the process of getting a job, starting a business, or continuing their studies.

Several studies showed that written and oral communication skills are consistently included in the top five skills desired by employers. According to the National Association of Colleges and Employers / NACE [33], the five personal qualities or skills that are considered by employers are (1) communication (verbal and nonverbal) skills, (2) strong work ethics, (3) team work skills (working well with other people and having a good communication in a group), (4) initiatives, and (5) analytical skills. Thus, one way to increase the students' competitiveness for their careers is to improve their ability to speak and write effectively.

Zincer [34] stated that some standards that help students to enter the workforce successfully or to continue their education to pursue their career are (1) application of academic skills, (2) career planning, (3) information development and presentation (verbal and non-verbal), (4) problem solving, (5) personal management, (6) 
organizational skills, (7) teamwork, (8) negotiating skills, (9) system understanding, and (10) employment of work skills.

In relation to these standards, the NACE's Job Outlook [35] study found that "when asked about the ability/quality of candidates, employers said that the most important of all is verbal communication skills". Further skills/qualities that are considered important by employers are as follows:

TABLE I. SKILLS / QUALITY CANDIDATES ASSESSED ARE IMPORTANT BY ENTREPRENEURS

\begin{tabular}{|l|l|c|}
\hline No & Skill/Quality & Average Value \\
\hline 1 & $\begin{array}{l}\text { The ability in verbal communication with people inside and } \\
\text { outside the organization }\end{array}$ & 4.63 \\
\hline 2 & The ability in team work & 4.62 \\
\hline 3 & The ability to make decisions and to solve problems & 4.49 \\
\hline 4 & The ability to plan, to organize, and to prioritize a job & 4.41 \\
\hline 5 & The ability to get and to process any information & 4.34 \\
\hline 6 & The ability to analyze quantitative data & 4.21 \\
\hline 7 & The work-related technical knowledge & 3.99 \\
\hline 8 & The proficiency in computer software program & 3.86 \\
\hline 9 & The ability to create and / or to edit written reports & 3.60 \\
\hline 10 & Ability to sell or influence others & 3.55 \\
\hline
\end{tabular}

Source: Job Outlook 2016, National Association of Colleges and Employers

The above table shows that communication skills get the highest value, i.e. 4.63, one point above the ability in team work and some points above the ability to solve problems. Thus, communication skill is essential to be improved. As early mentioned, business presentation is one of business communication skills [36]. In this context, business presentation is obviously inseparable from business sector [37]. To be sure, having impressive skill in business presentation can be such a remarkable career booster [38]. In conclusion, communication and presentation skills can benefit vocational students to achieve good careers such as getting a job quickly, taking a further study, and starting a business.

Based on the above discussion; the correlation between business communication skill and business presentation skill to encourage vocational school students' career success is illustrated as follows:

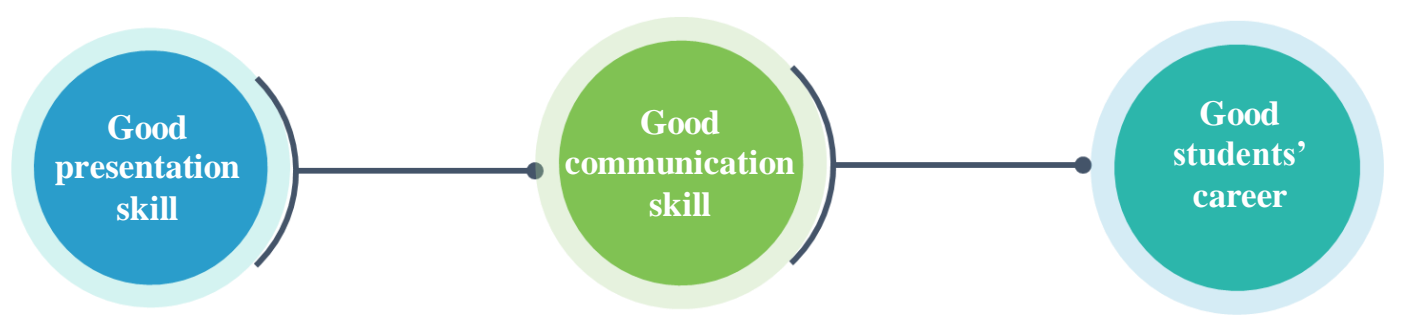

Figure 1. Communication Competencies and Business Presentation Related to the Successful Career of Vocational Students 


\section{CONCLUSION}

Based on the above literature study, it is clear to note that business communication and presentation skills provide students a better opportunity in getting a job, continuing a study, and starting a business. Communication and business presentation is one of the most important keys for the students' careers. By maximizing vocational students' communication and business presentation competencies, it is desirable to increase the competitiveness of the country, to reduce unemployment, and to overcome the lack of skills of the labor market. Thereby, a good business and economic performance can be materialized.

\section{REFERENCES}

[1] BPS. (2016). Pengangguran Terbuka Menurut Pendidikan Tertinggi yang Ditamatkan 19862016. Accessed on https://www.bps.go.id/linkTabelStatis/view/id/972.

[2] Çolakoğlu, N. \& Atabay,E. (2014). Job Satisfaction of the Academic Staff of the Vocational Schools of the Foundation and Public Universities Sample of Turkey. Quality Assurance in Education, Vol. 22 Iss 2 pp. 185-206.

[3] Nagle, J.P. (2001). Voices from The Margins: The Stories of Vocational High School Students. Joseph L. DeVitis \& Linda Irwin-DeVitis (Eds). New York.: Peter Lang Publishing

[4] Clarke, L. \& Winch, C. (2007). Vocational Education: International Approaches, Development and System, Oxon: Routledge.

[5] Curtis, D. B. Flyod, J. J. \& Winsor, J. L. (2003). Komuikasi Bisnis dan Profesional. Nanan Kandagasari, rina Komara, Yeti Pudjiyati. Jakarta. PT Rosda Jayaputra.

[6] Mas'ud, M \& Mahmud, M. (2008). Komunikasi Bisnis Modern: untuk Mahasiswa dan Profesi (2 $E d)$. Yogyakarta: Fakultas Ekonomi UGM.

[7] Cicala, J. E. Smith, R. K. \& Bush, A. J. (2012). What makes sales presentations effective - a buyer- seller perspective. Journal of Business \& Industrial Marketing, 27 (2), p.78-88. [Online]. Available at: doi:10.1108/08858621211196958.

[8] Gasskov, V. (2000). Managing Vocational training system. A handbook for Senior Administrators. Geneva: International Labor Office.

[9] Grosch, M. (2016). Developing A Competency Standard for TVET Teacher Education in Asean Countries Strengthening TVET in ASEAN Economic Community. ISSN: 2301-7147.pp 1-8.

[10] Nagle, J.P. (2001). Voices from The Margins: The Stories of Vocational High School Students. Joseph L. DeVitis \& Linda Irwin-DeVitis (Eds). New York.: Peter Lang Publishing

[11] Dit. Kerjasama Fungsional ASEAN. (2015, 7 Maret). Meningkatkan Daya Saing Melalui Pendidikan Kejuruan, Buletin Masyarakat ASEAN, Pp 20-21.

[12] Ahadi, (2017). Kelebihan dan Keunggulan Sekolah SMK Dibanding SMA. Accessed on. http://www.ilmusipil.com/kelebihan-dan-keunggulan-sekolah-smk-dibanding-sma.

[13] Siswandari. (2009). Peningkatan Kualitas Pembelajaran Statistika dalam rangka Mengembangkan Transferable Skills Mahasiswa. Jurnal Pemikiran dan Penelitian Pendidikan Tinggi AKADEMIKA. Volume 1, No. 1 January 2009. pp 23-32.

[14] Newman, A. \& Ober, S. (2013). Business Communication: In Person, In Print, Online (8 Ed). Mason (USA): South-Western.

[15] Purwanto, D. (2011). Komunikasi Bisnis. (4 Ed). Jakarta: Penerbit Erlangga

[16] Thill, J. V. \& Bovee, C. L. (2013). Excellence in Business Communication (10th Ed). New Jersey: Pearson.

[17] Newman, A. \& Ober, S. (2013). Business Communication: In Person, In Print, Online (8 Ed). Mason (USA): South-Western.

[18] Curtis, D. B. Flyod, J. J. \& Winsor, J. L. (2003). Komunikasi Bisnis dan Profesional. Nanan Kandagasari, rina Komara, Yeti Pudjiyati. Jakarta. PT Rosda Jayaputra. 
[19] Mas’ud, M \& Mahmud, M. (2008). Komunikasi Bisnis Modern: untuk Mahasiswa dan Profesi (2 Ed). Yogyakarta: Fakultas Ekonomi UGM.

[20] Cicala, J. E. Smith, R. K. \& Bush, A. J. (2012). What makes sales presentations effective - a buyer- seller perspective. Journal of Business \& Industrial Marketing, 27 (2), p.78-88. [Online]. Available at: doi:10.1108/08858621211196958.

[21] Burhanudin. (2015). Komunikasi Bisnis. Yogyakarta: Pustaka Pelajar.

[22] Johlke, M.C. (2006). Sales Presentation Skills and Salesperson Job Performance. Journal of Business \& Industrial Marketing, Vol. 21 Issue 5 pp. $311-319$.

[23] Purwanto, D. (2011). Komunikasi Bisnis. (4 Ed). Jakarta: Penerbit Erlangga.

[24] Campbell, L. G. (2003). The productivity and skills challenge. Industrial and Commercial Training. Vol. 35 Issue 3 pp. $99-103$.

[25] Garavan, T.N. \& McGuire, D. (2001). Competencies and workplace learning: some reflections on the rhetoric and the reality. Journal of Workplace Learning. Vol. 13 Issue 4 pp. $144-164$.

[26] Sengupta, A. Venkatesh, D.N. \& Sinha, A. K. (2013). Developing Performance-linked Competency Model: A Tool for Competitive Advantage. International Journal of Organizational Analysis, Vol. 21 Issue 4 pp. 504 -527.

[27] Sengupta, A. Venkatesh, D.N. \& Sinha, A. K. (2013). Developing Performance-linked Competency Model: A Tool for Competitive Advantage. International Journal of Organizational Analysis, Vol. 21 Issue 4 pp. 504 -527.

[28] Boak, L.M.G. (2009). Developing Competence Frameworks in UK Healthcare: Lessons from Practice, Journal of European Industrial Training, Vol. 33 Issue 8/9 pp. $701-717$.

[29] Guffey, M. E. \& Loewy, D. (2016). Essentials of Business Communication (10th Ed). Boston (USA): Chengange Learning.

[30] Thill, J. V. \& Bovee, C. L. (2013). Excellence in Business Communication (10th Ed). New Jersey: Pearson.

[31] The Saylor Foundation. (2012). Business Communication for Success. Accessed on http://www.saylor.org/books.

[32] Shimp, T.A. \& Andrews, J.C. (2013). Advertising, Promotion, and Other Aspects of Integrated Marketing Communications ( 9 Ed). Mason, USA: South-Western, Cengage Learning.

[33] National Association of Colleges and Employers. (2009). Frequently Asked Questions. Accessed on http://www.naceweb.org/Press/Frequently_Asked_Questions.aspx?referal.

[34] Zincer, R. (2003). Developing career and Employability Skills: A US Case Study. Educating + Training. Vol 45. Iss 7. pp. 402-410.

[35] National Association of Colleges and Employers. (2016). Employers: Verbal Communication Most Important Candidate Skill. Accessed on http://www.naceweb.org/careerreadiness/competencies/employers-verbal-communication-most-important-candidate-skill/.

[36] Locker, K. O. \& Kaczmarek, S. K. (2009). Business Communication Building Crotical Skills. New York: McGraw-Hill International Edition.

[37] Newman, A. \& Ober, S. (2013). Business Communication: In Person, In Print, Online (8 Ed). Mason (USA): South-Western.

[38] Patil, Z.N. (2005). Oral Presentation Skills for Prospective Business Executives. The Asian ESP Journal. ISSN 2206-0979 (Online) https://www.asian-esp-journal.com/2005/12/04/oralpresentation-skills-for-prospective-business-executives/ 